\title{
ПРАВОВОЕ РЕГУЛИРОВАНИЕ СОЦИАЛЬНО-ЭКОНОМИЧЕСКИХ ПРОБЛЕМ «МУСОРНОЙ РЕФОРМЫ»
}

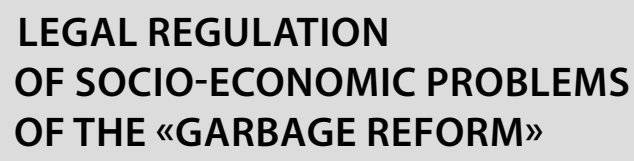

LEGAL REGULATION

OF SOCIO-ECONOMIC PROBLEMS OF THE «GARBAGE REFORM»

A. Lobko

Summary. This work is aimed at forming a comprehensive and systematic approach to the study of financial and legal problems in the implementation of the Federal project «Integrated system for solid municipal waste management (MSW)» (commonly called "garbage reform»). (riticism of organizational, legislative, financial and other aspects of the "garbage reform» is given. The methodological basis of scientific development is a system of philosophical, General scientific and special legal means and methods of knowledge that ensure objectivity, historicism and comparativism (comparative legal method) of studying issues at the intersection of financial and civil law. These include: maximum collection of reliable information on the research topic, analytical and logical analysis, specificity, cultural and historical search, analogy, legal interpretation, and other means of examining socio-economic and legal problems. As a result of the study, the principal shortcomings of the «garbage reform» were identified, which do not allow creating an effective waste disposal system. Specific recommendations are given for their elimination, which will improve the socio-economic situation in the environmental sphere.

Keywords: financial law, new municipal service «handling of MSW», Russian environmental operator, competitions, regional operators, garbage protests, Paris climate agreement, greenhouse gas emissions, incineration with recycling, dioxins, reclamation, investment, fictitious services, environmental tax.

\author{
Лобко Анастасия Александровна \\ МГУ им. М.В. Ломоносова \\ naty.rubik@mail.ru
}

Аннотация. Данная работа нацелена на формирование комплексного и системного подхода к изучению финансово-правовых проблем в ходе реализации федерального проекта «Комплексная система обращения с твердыми коммунальными отходами (ТКО)» (общепринятое название «мусорная реформа»). Дается критика организационных, законодательных, финансовых и других аспектов «мусорной реформы». Методологической основой научной разработки является система философских, общенаучных и специально-юридических средств и способов познания, обеспечивающих объективность, историзм и компаративизм (сравнительно-правовой метод) изучения вопросов на стыке финансового и гражданского права. В их числе: максимальный сбор достоверной информации по теме исследования, аналитико-логический анализ, конкретность, культурно-исторический поиск, аналогия, юридическая интерпретация и другие средства обследования социально-экономических и правовых проблем. В результате исследования были выявлены принципиальные недостатки «мусорной реформы», которые не позволяют создать действенную систему утилизации отходов. Даны конкретные рекомендации по их устранению, которые улучшат социально-экономическую обстановку в экологической сфере.

Ключевые слова: финансовое право, новая коммунальная услуга «0бращение с ТКО», Российский экологический оператор, региональные операторы, мусорные протесты, Парижское соглашение по климату, выбросы парниковых газов, диоксины, рекультивация, инвестиции, фиктивные услуги, экологический налог.
$\Phi$ инансовое право, как юридическая дисциплина, объективно базируется на доскональном изучении реальных общественных процессов (по большей части в экономико-социальной сфере), связанных с формированием, распределением и использованием денежных средств. Кроме того, финансовое законодательство находится в неразрывной взаимосвязи с другими разделами юриспруденции и прежде всего с гражданским правом. Несоблюдение данного утверждения, подмена обоснованных фактов эмоциональными рассуждениями с целью искусственного поднятия рейтинга власти приводит к оторванности разрабатываемых законов от конкретной практики, делает принятые нормы невыполнимыми, приносящими больше вреда, чем пользы. Это наглядно подтверждает анализ официально стартовавшей в России, за исключением городов-героев Москвы, Санкт-Петербурга (Ленинграда), с 1 января 2019 года «мусорной реформы» [6, 7].

По мере накопления бытовых отходов и, что важно, роста объема производимого цивилизацией мусора вопрос о том, что с ним делать, становится все более острым. Напряжение в процессе реализации «мусорной реформы» накаляется с каждым днем. Данный предмет внимания в условиях, когда страна задыхается от экологической нагрузки, превратился сегодня в одно из наиболее актуальных ключевых социально-экономических явлений, требующих тщательного и всестороннего научного исследования. Прежде всего непредвзятого анализа экономико-правовой составляющей этих собы- 
тий вследствие достигшей катастрофических размеров беспрецедентной экологической проблемы мусора. Реалистическая оценка её хронического состояния при непрерывной официальной демагогии и установившейся системе тотальной лжи показывает, что объективно в массовом сознании россиян происходит накопление общего раздражения. Такая реакция коллективного восприятия действительности свидетельствует об очевидной экстраординарной ситуации в экологии и является индикатором недовольства, напряжения, нестабильности в обществе. Стало очевидным, что предложенная явно популистская модель не работает в полной мере ни экономически, ни организационно, ни юридически. Даже спустя полтора года «мусорная реформа» находится в коматозном состоянии, поскольку российское правительство, к сожалению, продемонстрировало свою способность игнорировать действительность и лицемерить на грани помешательства.

Во исполнение указа Президента России от 7 мая 2018 года № 204 [9] профильным Министерством природных ресурсов и экологии Российской Федерации (Минприроды РФ) в экстренном порядке был разработан и утвержден президиумом Совета при Президенте Российской Федерации по стратегическому развитию и национальным проектам [10] национальный проект «Экология» на 2019-2024 гг., в состав которого был включен федеральный проект «Комплексная система обращения с TKO» (или «мусорная реформа»). Но прогрессивная идея создания практически новой современной отрасли, связанной с твердыми бытовыми отходами (TKO), оказалась невыполнимой. «Мусорная реформа» (и это очевидно) уже провалилась, так как она оторвана от конкретности и антисоциальна, является фикцией ради разворовывания денег из бюджета и карманов граждан. К этой реформе оказалась не готова вся страна. Она и не могла быть готова, поскольку накопившиеся нерешаемые десятилетиями проблемы попытались решить непрофессионально, кавалеристским наскоком за неполный год. Процесс «мусорной реформы» шел с издержками, перегибами, на которые в силу большой спешки (а то и некомпетентности и чьих-то корыстных интересов) закрывали глаза. По откровенному признанию В.С. Кузнецова, генерального директора НП «Центр экологических инициатив», «задача нынешней власти не инфраструктурные проекты по борьбе с мусором воплощать, а вывозить собранные с населения деньги в офшоры» [37].

Из-за разочарования общественного мнения в созданной организационно недоработанной и деградирующей схеме не удастся в ближайшей перспективе уменьшить последствия мусорного коллапса в стране, значительно сократить негативное воздействие на окружающую среду. Идеологи реформы, «наследники хаоса» непростительно не придали значения важной и по сей день актуальной мысли франко-швейцарского философа Жан-Жака Руссо (1712-1778 гг.): «Мудрый законодатель начинает не с издания законов, а с изучения их пригодности для данного общества» [34].

К счастью, российское общество, в отличие от разработчиков реформы, все в большей степени основывает свои суждения не на фантазиях и громких заявлениях-обещаниях, а на осознании реалий, понимании, что легких решений у сложных проблем не бывает. Маятник общественного мнения качнулся в противоположную от разработчиков сторону: среди российских граждан стали массово преобладать априори негативные и циничные взгляды на конкретные недостатки «мусорной реформы» и ее реализации. Показательно, что ответственный за создание нововведений, глава Минприроды РФ (бывший губернатор Ямало-Ненецкого автономного округа) Д.Н. Кобылкин, 13 марта 2020 г. на заседании комитета Совета Федерации по экономической политике был вынужден официально заявить, что не стоит строить иллюзий по поводу быстрой перестройки сферы утилизации отходов в РФ. Даже в лучшем случае она займет не менее 10 лет. Под давлением неоспоримых фактов он вынужденно признал, что решить волюнтаристическими методами, как первоначально предполагалось, за один-два года экстерном многочисленные вопросы вывода из паралича мусорной отрасли невозможно. Прежняя «уверенность» оказалась, по сути, «пустым звуком», проявлением невежества, а не знания. Фактически новое заявление о сроках осуществления реформы явилось убедительным доказательством открытого канадским педагогом П. Лоуренсом (1919-1990 гг.) «принципа Питера», когда на ответственных должностях часто оказываются некомпетентные люди, склонные переоценивать собственные умения и неспособные осознавать всю глубину своей некомпетентности [28].

Коротко суть нововведений в понятие «Обращение с ТKO» можно сформулировать следующими положениями: передача полномочий по организации системы обращения с твердыми бытовыми отходами (ТБО) на региональный уровень; выделение новой услуги «Обращение с ТКО» в отдельную строку в платежных документах граждан за коммунальные услуги (то есть собственники жилья должны знать, за что они платят); полная замена схемы по обращению с TKO; привлечение в качестве исполнителя реформы выбранных по конкурсу «региональных операторов»; формирование платежей за сбор и вывоз мусора по новой схеме; возложение общего руководства и контроля за «Обращением с ТКО» на вновь созданную публичную правовую государственную компанию «Российский экологический оператор» (РЭО) [11]. 
Анализ основных положений «мусорной реформы» убедительно показал, что принятое скрытно, «за закрытыми дверями» новое законодательство по регулированию «мусорной сферы» содержит множество сомнительных норм, которые ограничивают и нарушают права жителей. Население противоправно вынуждают оплачивать по завышенным, «накрученным» (в том числе за счет двойного начисления) ценам новую коммунальную услугу «Обращение с TKO», даже когда она вообще не оказывается. Например, россиян пытаются заставить раскошеливаться независимо от того, заключали ли они договор с региональным оператором. В соответствии с постановлением правительства от 12.11.2016 № 1156, если потребителю не направили заявку на заключение договора с региональным оператором, договор считается заключенным автоматически на 16-й день, с момента опубликования на сайте регионального оператора предложения заключить договор. K тому же акцептом (лат. acceptus - «принятый») этой оферты (лат. offero - «предлагаю») будет не только оплата коммунальной услуги, но также ее потребление [16]. Это во многих конкретных случаях явно противоречит статье 30 п. 5 Жилищного кодекса РФ [5], согласно которой собственник обязан вознаграждать регоператора за обращение с ТКО путем добровольного, а не принудительного заключения договора (и только тогда, когда есть сам предмет договора - ТKО). В случаях отсутствия ТКО их транспортировка, обезвреживание, захоронение невозможны, следовательно, силком заключаемый договор автоматически становится нелегитимным.

Ещё более абсурдна норма, когда разработчики реформы совершенно несправедливо заставляют людей осуществлять плату за коммунальную услугу «Обращение с TKO» не по числу проживающих в квартире лиц, а по количеству квадратных метров. Такое абсолютно нелогичное правило, естественно, вызвало в массовом порядке обоснованное возражение граждан, поскольку, например, одиноко проживающий в четырехкомнатной квартире российский пенсионер-инвалид почему-то должен оплачивать намного больше, чем десять мигрантов-среднеазиатов трудоспособного возраста, которые ютятся в малогабаритной съемной однокомнатной квартире.

Целиком незакономерно и принятое положение в случаях, когда у человека в собственности несколько квартир, но проживает он постоянно только в одной, отчего его необоснованно пытаются заставить оплачивать за обращение с ТKO по количеству метража по всем квартирам.

Наибольшее беспокойство населения вызывает те случаи, когда регоператоры умышленно отказывают россиянам сделать положенный по закону «О защите прав потребителей» [3] перерасчет по коммунальной услуге «Обращение с ТКО» в случаях временного отсутствия проживающих в конкретной квартире только из-за того, что законодатели «мусорной эпопеи» якобы «забыли» предусмотреть это в нормативных актах. По их версии, перерасчет невозможен, поскольку в принятых правовых нормах плата исчисляется от количества метров, а не числа проживающих.

Следующий необоснованный пункт, который вызывает не меньшую массу претензий,- это необходимость оплачивать вывоз крупногабаритных отходов (КГО) дополнительно к нормативу на обращение с ТКО. То есть создатели реформы утвердили норматив с ТКО и отдельно еще и норматив на вывоз КГО. Между тем приказ Федеральной службы по надзору в сфере природопользования (Росприроднадзор) четко гласит, что КГО уже входят в число ТКО. Таким образом, расходы на вывоз КГО заранее были включены в норматив по обращению c TKO.

Действующее прежде понятие ТБО официально не применяется с конца 2014 года. Модернизированный термин ТКО стал трактоваться намного шире. Кроме бытового мусора, сюда стали относиться и другие категории: производственные отходы (например, остатки промышленных материалов, пластик, контейнеры или тара для хранения материалов на производстве); мусор, образуемый на предприятиях по оказанию услуг населению (в парикмахерских, общепите, салонах красоты, спортзалах, магазинах, торговых центрах); мусор, образующийся в офисах (например, канцтовары, бумага); отходы из школ или других детских учебных учреждений; хозяйственные или промышленные предметы, утратившие свои рабочие качества (например, отработанная оргтехника, электроника, бытовая техника); КГО, в том числе мебель, крупная бытовая техника, двери, оконные рамы, ковры, линолеум и т.д. [22].

Главное различие между бытовыми и коммунальными отходами - сфера их образования. Бытовые отходы - это мусор, образующийся в результате частной жизни людей, коммунальные отходы образуются везде, где находится человек: в торговых центрах, офисах, школах, ресторанах, на заводах, в парикмахерских, парках, театрах и т.д. [6]. Получается, что плату незаконно взыскивают с населения повторно. Кроме того, граждане оплачивают при покупке производителю и продавцу упаковку товара. А потом они дополнительно должны еще и заплатить за утилизацию этой упаковки.

Так как вывоз мусора теперь выносится в квитанции отдельной строкой в разделе «Коммунальные услуги», плата за данный сервис должна быть, естественно, исключена из строки «Содержание и ремонт жилого по- 
мещения». Управляющие компании (УК) были обязаны сделать это сразу же с момента вступления в регионе новых правил утилизации ТКО (п. 8.1. ст. 23 ФЗ № 458 от 29.12.2014 (ред. от 03.04.2018) [6]. Размер платы по строке «Содержание и текущий ремонт жилья» УК должны были уменьшить ровно на ту составляющую платежа, которая тратилась ими на самостоятельный вывоз мусора. Более того, УК обязаны были предупредить собственников об изменении платы за услугу, причем не позднее, чем за 10 дней до того, как изменения вступили в силу. Также по требованию жильцов управляющая организация обязана была предоставить им документы, обосновывающие новый размер платы за услугу.

Однако, например, жители Московской области второго по численности населения региона России в течение года оплачивали уборку мусора по двойной цене. В квитанциях организованного властями для сбора денег по оплате за ТКО аффилированного посредника - ООО «МособлЕИРЦ» - строка по сумме платежа за содержание жилья не изменилась. Обоснованные претензии об исключении задвоенного платежа и перерасчете неверных начислений в УК просто игнорируются, поскольку деньги по двойному тарифу перечислялись непосредственно платежному агенту (оператору по сбору денег) ООО «МособлЕИРЦ». Не помогают даже обращения с жалобами в Госжилинспекцию. Хотя, согласно изменениям, внесенным в правила осуществления деятельности по управлению многоквартирными домами (МКД), утвержденным Постановлением Правительства № 416 [14], срок ответа на жалобу в УК составляет всего три дня, а размер штрафа за неверные начисления установлен 50\% от неправомерно начисленной суммы. Тем не менее в Подмосковье повсеместно перерасчеты не делаются, поскольку УК полностью отстранены по указанию властей от сбора оплаты за ЖКУ в пользу посредника ООО «МособлЕИРЦ». Данное ООО, не оказывая никаких конкретных коммунальных услуг лишь имитирует «деятельность», аккумулируя на своих счетах многомиллиардные платежи с огромного региона.

Более того, в целях устранения какой-либо возможности государственного контроля своего функционирования, в нарушение ФЗ от 7 августа 2001 г. № 115 [4] и п. 2 Постановления Правительства РФ от 27 января 2014 г. № 58 [15], ООО «МособлЕИРЦ», по данным из МРУ Росфинмониторинга, даже не состоит на учете как оператор по приему платежей.

По новым правилам в состав коммунальной услуги «Обращение с ТКО» входят только сбор, транспортировка, проведение обезвреживающих процедур и выгрузка отходов. Региональный оператор отвечает за реально выполненную работу с момента погрузки мусора в специальную машину до сброса груза на специальных площадках. Если новая коммунальная услуга «Обращение с TKO» практически не относится к услугам на общедомовые нужды, то данный коммунальный сервис должен быть оплачен, только если он реально оказан. В Определении Высшего Арбитражного Суда (ВАС) РФ указывается, что из ст. 781 ГК РФ не следует обязанность заказчика по оплате не оказанных ему исполнителем услуг [2].

Поскольку многие граждане (до 20\% численности от населения Московской области) не проживают в расположенных в Подмосковье жилых помещениях МКД, где они являются собственниками, и квартиры в наем не сдаются, то по этим адресам образование твердых коммунальных отходов не происходит и не может происходить даже теоретически, следовательно, реально региональный оператор объективно не может оказать данную услугу, так как отсутствует сам предмет (юридически мусором называются любые предметы или вещества, образовавшиеся в процессе потребления, производства, оказания всевозможных услуг или выполнения различных работ и подлежащие удалению) для заключения типового договора. Отсутствие у заказчика-гражданина необходимости в получении услуг по «Обращению с ТКО» в период действия договора объективно не может расцениваться как виновное поведение заказчика, влекущее обязанность оплатить фактически не оказывавшиеся услуги. Нормы статьи 781 ГК РФ [2] не являются императивными (императивная норма права - правовое предписание, которое во всех случаях обязательно для адресатов и не может быть изменено их соглашением), в связи с чем стороны имели возможность предусмотреть обязанность заказчика вносить те или иные сборы и платы независимо от реального оказания услуг. Однако типовой договор таких условий не содержит. Таким образом, сбор за обращение с ТКО не может взиматься подмосковными регоператорами через ООО «МособлЕИРЦ» без предоставления реальных услуг по уборке несуществующего мусора.

Исходя из содержания п. 1 ст. 779 ГК РФ [2], очевиден вывод, что у собственника обязанность по уплате денежных средств возникает только при получении реальных услуг от исполнителя. Тем не менее в нарушение законодательства УК (даже когда УК было многократно извещено должным образом об отсутствии проживающих и зарегистрированных в квартире) не оказывали регоператорам при заключении типового договора никаких информационных услуг в отношении данного жилого помещения, и регоператоры не вправе требовать уплаты денежных средств через посредника ООО «МособлЕИРЦ». Тем более что факт оказания услуг не может быть подтвержден актами сдачи-приемки выполненных работ и услуг, поскольку нет даже предмета (мусор 
по конкретному помещению не образуется) типового договора.

Следует, бесспорно, учитывать, что одновременно собственники, имеющие квартиры, где мусор не образуется из-за отсутствия проживающих, оплачивают коммунальную услугу «Обращение с TKO» по адресу фактического проживания, т.е. там, где есть предмет договора. Это вытекает из содержания ст.ст. 779-781 ГК РФ [2], так как обязанность оплаты услуги возникает у потребителя при оказании исполнителем и потреблении потребителем этой реальной, а не фиктивной услуги.

На наш взгляд, необходимо в платежных документах указывать разграничение структуры оплаты для определения безусловной обязанности собственника жилого помещения нести расходы по содержанию этого помещения пропорционально своей доле как бремя содержания имущества и обязанности как потребителя услуг оплачивать только те коммунальные услуги, которые фактически собственнику предоставлялись и которыми имелась возможность реально пользоваться. Фиктивные же счета-приписки аффилированных недобросовестных посредников типа ООО «МособлЕИРЦ» (т.е. являющихся непосредственным участником противоправной финансовой схемы по максимальному сбору денежных средств с населения в пользу региональных операторов без имеющихся на то оснований) подлежат аннулированию и перерасчету. $B$ структуре коммунальных услуг необходимо обязательно выделять услуги, оплата которых зависит от фактического пользования ими потребителем, и услуги, которые подлежат оплате независимо от пользования ими, только если они влияют на поддержание в надлежащзем состоянии жилого помещчения собственника.

В данной ситуации сбор средств с собственника через посредника ООО «МособлЕИРЦ» в МКД для оплаты коммунальной услуги, которая абсолютно не оказывается, однозначно противоречит Конституции РФ [1], поскольку собственник жилья в этом случае вынужден оплачивать коммунальное обслуживание «Обращение с TKO» за других, т.е. за не принадлежащее ему имущество. При существующей норме региональный оператор, например, ООО «Хартия» (греч. chartion - «бумага, грамота»), фактически стремится получать в коррупционном сговоре-тендеме с компаниями по сбору денег (например, ООО «МособлЕИРЦ») и их антиконституционными методами работы незаконное право распоряжаться перечисленными средствами без ведома собственников, в том числе за чужой мусор. Антиконституционные действия, когда региональные операторы через посредников по сбору денег незаконно понуждают собственников оплачивать то, чего нет и быть в принųипе не может, недвусмысленно квалифицируются по Уголовному кодексу (УК РФ) как мошенничество. Тем не менее правоохранительные органы, которые содержатся на налоги граждан, «сознательно» не принимают никаких мер к явным нарушителям в сфере ЖКУ в коррупционной связке с местными властями. Следует также учитывать, что, поскольку многие собственники жилья, например, в Подмосковье, проживают постоянно в другом регионе (г. Москва и другие регионы РФ), платежная нагрузка на социально уязвимую часть из них возрастает, так как им не положены льготы для лиц пенсионного возраста, ветеранов труда и инвалидов - жителей Подмосковья, где расположена недвижимость.

Проверки выявили, что тарифы на услуги региональных операторов и нормативы накопления ТКО практически во всех регионах страны были утверждены местными властями без должного обоснования в сторону завышения. При этом методику формирования тарифа осуществляли непосредственно заинтересованные в максимально высоких тарифах региональные операторы. Мнение людей региональные власти нагло проигнорировали, никто их не спрашивал, никакого народного обсуждения тарифов не было, просто поставили перед фактом: платите больше. Поэтому граждане имеют законное право проводить акции протеста, в связи с чем Правительство РФ было вынуждено принять изменения в Основы ценообразования в области образования ТKО (документ подготовлен Федеральной антимонопольной службой - ФАС) по снижению тарифной нагрузки на население из-за того, что приоритетом деятельности отобранных «по конкурсу» региональных операторов с самого начала их утверждения являются: алчное отношение к окружающим, исключительно шкурные интересы, максимальная нажива за счет граждан, а не решение актуальных проблем ухудшающейся в стране экологии.

Безусловно, несправедливо, что траты на инфраструктуру «мусорной реформы» власти перекладывают на плечи жильцов. Ведь население России уже и так оплачивает непомерные при низком уровне жизни налоги. Огромное желание властей насильно, без согласия собственников брать деньги на строительство мусороперерабатывающих заводов и других «мусорных» объектов со стоимости коммунальной услуги «Обращение с ТKO» с точки зрения закона требует создания акционерного общества. Каждый плательщик должен быть его акционером. Разумеется, жителям как акционерам полагается иметь определенное количество акций в соответствии со стоимостью коммунальной услуги «Обращение с ТKO». Тогда акционеры будут конкретно спрашивать с руководства акционерного общества за ход преобразований по утилизации мусора. Но власти намеренно нигде не говорят, что в стоимость тарифа будет входить инвестиционная составляющая на строительство новых мощностей по переработке мусора. 
Перечисленное даже далеко не в полном объеме позволяет сделать очевидный вывод о том, что в нынешнем виде «мусорная реформа» не отвечает интересам граждан и является очередным этапом по необоснованному увеличению платы за ЖКХ и обиранию населения. Государство тщетно пытается бороться с явлением, а не с причинами, его вызывающими. Вместо того, чтобы сначала привлечь реальных инвесторов, вложить деньги, построить современные заводы и инфраструктуру, а уже потом предлагать людям новую систему оплаты за обращение TKO, чтобы россияне чётко понимали, за что они должны платить больше, разработчики реформы поставили «телегу впереди лошади» и стали массово закрывать полигоны, не подготовив заранее новые варианты утилизации мусора.

Изменение понятий в связи с объявлением «мусорной реформы» - это не только психологический прием влияния на сознание человека, в ходе реализации которого названия, закрепленные в сознании и несущие определенные эмоциональные реакции, подменяются другими словами или терминами. Но и возможность регоператоров незаконно ссылаться, к примеру, на различные «ведомственные» письма из министерств правительства России и их структурных подразделений, в которых «разъясняются» вопросы применения нормативных правовых актов, но не содержатся правовые нормы. Эти «ведомственные» письма, как общеизвестно, являются всего лишь односторонней и предвзятой необъективной экспертной позицией ведомства. И, следовательно, не могут быть направлены на установление, изменение или отмену правовых норм, а содержащиеся в них разъяснения не могут рассматриваться в качестве обязательных государственных предписаний постоянного или временного характера. В частности, это касается неправомерного утверждения, основанного на неверном толковании норм закона, что региональный оператор якобы может в нарушение Конституции РФ (!) не делать перерасчет, когда в квартире никто не зарегистрирован и не проживает по новой коммунальной услуге «Обращение с TKO», если за расчетную единицу берется квадратный метр общей площади жилого помещения, поскольку порядок перерасчета не предусмотрен (?!). Хотя законодательство РФ однозначно предусматривает перерасчет платы за неоказанные коммунальные услуги «Обращуение с ТКО» в связи с временным отсутствием потребителя. Более того, любому здравомыслящему человеку понятно, что сам по себе квадратный метр не может образовывать omxodbl.

По нашему мнению, принуждение индивида платить за мусор, которого нет, должно осуществляться лишь в соответствии с универсальными, общими для всех правилами и нормами, обладающими правовой сущно- стью, а не отражающими волю отдельно взятых групп интересов. Гарантом соблюдения законодательства должна стать его правовая основа, а не угроза применения к энным нарушителям легитимного насилия со стороны государства, отличительными чертами которого стали специализированный налоговый, полицейский и судебно-приставной аппарат, с одной стороны, и криминальная коллекторская (в большинстве случаев) структура - с другой. (С точки зрения закона, коллекторы - это «юридические лица, осуществляющие деятельность по возврату просроченной задолженности в качестве основного вида деятельности». Как правило, коллекторы ведут работу по взысканию долга в пользу управляющих компаний ЖКХ с грубейшим нарушением законодательства. Часто выкупают долги по договорам уступки прав требования и после этого взыскивают долги уже в свою пользу.)

Неизменным принципом осуществления правосудия должен выступать принцип равенства всех перед законом. В обратном случае законодательный орган будет продолжать принимать лишь удобные для него законы, не попадая под действие неугодных ему норм права. Создание же правового государства и развитие институтов гражданского общества является неотъемлемым условием формирования демократической формы социально-политического устройства современной России, что, в свою очередь, становится возможным лишь в условиях должного взаимодействия общества и государства.

Организаторы реформы и ее настоящие (не офшорные) «благополучатели» - граждане России - живут в разных явях. В условиях затянувшегося на долгие годы периода прозябания и стагнации, при стабильно очень низком, вялом темпе развития страны в целом, высоком уровне коррупции, долговременном падении цен на нефть и снижении курса рубля предложенная модель модернизации системы обращения с TKO на практике оказалась непродуманной, спонтанной и хаотической. В такой ситуации центр общественных интересов и споров неминуемо смещается от умозрительных и историко-философских проблем в сторону конкретных вопросов об устойчивости и конкурентоспособности страны, к обсуждению проблемы национального выживания. Ложь чиновников о «мусорной реформе» стала оправданной манерой поведения. Произошло падение доверия большинства населения к «мусорным преобразованиям», которые спустя полтора года с их начала не приблизили даже надежду на урегулирование проблем с ТКО. Более того, обернулись для населения новыми отрицательными побочными последствиями. По экспертной оценке главы комитета по торговле «Деловой России» А.В. Фёдорова, из-за ужесточения экологических требований к утилизации бизнес прогнозирует рост цен на непродовольственные товары. Бытовая 
техника (холодильники, стиральные машины, пылесосы и т.д.) может подорожать на 13\%, электроника - на 9\%, одежда и обувь - на 2-5\%. Цены подскочат, поскольку с 2021 года вступят в силу нормативы, предполагающие стопроцентную утилизацию отходов потребительских товаров и упаковки [42]. Представитель ассоциации, в которую входят Indesit, LG, Samsung, Sony и Whirlpool, объяснил, что фактически это приведет к новому налогу на оборот.

Отправленное (неожиданно срочно) в январе 2020 года в полном составе в отставку крайне непопулярное «медведевское» антинародное правительство РФ [12] за почти восемь лет его существования не ознаменовалось ничем хорошим в истории России. У правительства вошло в привычку безнаказанно отмахиваться от проблем. Создавать только на словах иллюзию благополучия, направленную на успокоение и обман российского населения. Неудивительно, что результаты «мусорной реформы» вылились в очередной распил бюджетных денег и массовые протесты. Итоги оказались настолько плачевными, что бюрократическая импотенция правительства породила новое опасное явление - острую реакцию общества на резонансные высказывания чиновников. Скандальные заявления по поводу «мусорной реформы» стали не только трендом медийного пространства, но и реальным феноменом современной российской политики. Если раньше неосторожные высказывания чиновников воспринимались народом как досадный казус, то по мере роста таких прецедентов они стали рассматриваться все серьезнее, превращаясь в меткие анекдоты, устойчивые фразы образного или афористического характера (например: «Ты виноват уж тем, что хочется мне денег», относящееся, в частности, к «выбранным» регоператорам типа ООО «Рога и копыта»), демонстрируя разобщенность, провоцируя социальное недовольство и усиливая протестные настроения, могущие даже раскачать основы власти. Громкие неподготовленные высказывания чиновников грандиозно и надолго провалили старт «мусорной реформы» своей глупостью и жадностью, сформировав у общества и экспертов изжогу ко всему «мусорному». В России уже не верят ни в сжигание и переработку, ни в рекультивацию и сортировку, но точно знают: если где-то затевается проект с отходами или растет свалка, то кто-то одновременно покупает за рубежом виллу, пока граждане «обалдевают» от очередных мусоросжигательных заводов, технопарков и прочих Шиесов и ООО «МособлЕИРЦ».

Например, неудачная попытка завуалировать «мусорный абсурд» современным придворным глашатаем - нынешним главой Совета по развитию гражданского общества и правам человека (СПЧ) - на форуме «Чистая страна» в Сколково (2019 г.) привела лишь к заметным отрицательным последствиям. Оглашение им в качестве эксперта и советчика на все случаи жизни очередной порции пустопорожнего вздора и дезинформации только усилило мнение о СПЧ как о необъективном и лояльном к руководству страны органе, стремительно теряющем общественные симпатии. Фактически создало этому блоку репутацию «слабого звена», полноценного прислужника, произносящего с апломбом, умным и значительным видом банальщину, рупора действующей власти [40].

Реализация федерального проекта «Комплексная система обращения с ТКО» нацелена на эффективное обращение с отходами производства и потребления, включая ликвидацию всех выявленных на 1 января 2018 г. несанкционированных свалок в границах городов.

По данным Росприроднадзора, сейчас в России 295 объектов обработки коммунальных отходов, $119-$-утилизации. К 2024 году стоит задача подойти к 36\% утилизации (переработка отходов) и 60\% обработки (сортировка). Должны быть построены заводы по переработке общей мощностью 37 млн. тонн [17]. Но в сложившейся в российском обществе системе государственно-олигархического капитализма, характеризующейся фактически беспринципным обиранием населения, следствием которого является его обнищание, с прожиточным минимумом, который в России на уровне минимума физиологического выживания, и достаточно серьезным разрывом в уровне благосостояния субъектов федерации [27], это в принципе невыполнимо. К тому же надо учитывать, что в проекте будут участвовать появившиеся «по конкурсу» структуры (ООО), главная первостепенная цель которых одна - максимально собирать деньги с обнищавшего населения.

Предполагается, что созданный для руководства и контроля РЭО будет стимулировать инвестиции в области обращения ТКО и создаст систему вторичной переработки сырья. Для чего РЭО наделено обширными регуляторными и финансово-экономическими полномочиями? Наблюдательный совет компании возглавляется на уровне вице-премьера правительства. Госкомпания с функциями министерства в том числе будет готовить проекты законов, распоряжаться бюджетными деньгами, строить объекты инфраструктуры и оказывать услуги в области управления отходами. При этом госмонополист сможет входить в капитал компаний отрасли, вплоть до стопроцентного участия. Иными словами, в России начался очередной передел отрасли управления отходами в пользу федеральной монополии.

Развитие «мусорной реформы» тормозят несовершенство законодательной базы и нормативных документов, неопределённость финансирования мероприятий, которые прописаны законом как обязательные. 
Упущено много драгоценного невосполнимого времени, чтобы исправлять допущенные промахи и урегулировать проблемы, доставшиеся по наследству. На наш взгляд, успешное решение «мусорной проблемы» может быть достигнуто лишь тогда, когда заинтересованное, энергичное, отражающее волю подавляющей части населения большинство действует справедливо и только в рамках установленных общих правил. В случае отсутствия таких законодательных норм это будет лишь выражением безмерной воли социума, различные группы которого стремятся достичь собственных целей, рассчитывая на получение благ и привилегий со стороны властей.

К сожалению, в условиях ослабленной, топчущейся на месте экономики, на фоне эпидемии коронавируса, падения цен на нефть и замедления деловой активности складывается атмосфера, при которой для решения «мусорной проблемы» любая группа общества готова пойти на зачастую неправомерные уступки в предоставлении благ и привилегий другой группе, если будет уверена в гарантированной ответной благодарности. Государственные структуры (РЭО и другие), ответственные за решение проблемы мусора, начинают реализовывать собственные, отличные от общественных целей задачи.

Исследуя работу такого теневого механизма, нобелевский лауреат по экономике 1974 года Фридрих фон Хайек сделал вывод о том, что в этой системе одна группа людей может объявить все, что ей угодно, делом важным для всех, чтобы на этом основании использовать общепризнанную процедуру для проведения в жизнь исключительно своих решений [35]. Иными словами, общество оказалось оторванным от создания действенных законодательных правил по борьбе с мусором. Работа с огромными финансовыми средствами, необходимыми для решения «мусорных проблем», стала сразу порождать незапланированные и зачастую нежелательные и сомнительные частные структуры - ООО. Уже с самого начала проявились принципиальные недостатки в организации реализации основных оторванных от практики положений реформы. Так, планировалось напрямую получить регоператора-бизнесмена, который своими деньгами полностью отвечает перед государством и населением за то, что делает. И отделить губернаторов и местные власти от регоператоров, чтобы последние начали координировать работу с РЭО. Рассчитывали, что это произойдет быстро и региональная власть не станет вмешиваться в тот или иной бизнес, а будет видеть и спрашивать только результат работы.

Однако из-за недоработки властей на местах при объявлении конкурса по выбору региональных операторов получалось так, что ими часто становились ООО без оборотных средств, перевозочных мощностей и сортировочного комплекса, которые не включили в тариф инвестиционную составляющую. Как неизбежное следствие - в неустойчивом финансовом состоянии оказалось около 15-20\% регоператоров. Сегодня существуют риски банкротства уже не менее 11 региональных операторов, потому что они понесли достаточно серьезные первоначальные затраты на закупку мусоровозов и обустройство контейнерных площадок. В ряде регионов России возникла критическая ситуация, связанная с вывозом мусора. «Мусорная катастрофа» уже началась в Алтайском и Красноярском краях, ряде областей (Вологодской, Курской, Магаданской, Новгородской и Новосибирской, а также Томской и Челябинской), республиках - Бурятии, Дагестане, Ингушетии, Северной Осетии, Туве, Кабардино-Балкарии [31].

Очевидно, что многие «мусорные» регоператоры вместо налоговых поступлений обанкротятся и рано или поздно уйдут с рынка. Минприроды России было вынуждено в очередной раз предложить за счет бюджета (т.е. налоговых сборов павшего в нищету большинства населения России) покрыть долги регоператорам за вывоз мусора, привести в порядок контейнерные площадки, а также начать информационную кампанию по повышению собираемости платежей. Не исключена даже возможность выплаты компенсаций региональным «мусорным» операторам и очередная переоценка нормативов накопления ТКО. Власти почему-то по-прежнему безосновательно (а потому и безрезультатно) ждут от таких «компаний-пустышек» с уставным капиталом в 10 тысяч рублей инвестиций на сотни миллионов рублей и даже заключают концессионные (от лат. concessio - «разрешение, уступка») невероятные по суммам соглашения с фирмами, в штате которых работает несколько человек. Способность данных ООО ввести в заблуждение начальство объясняется только коррупцией, которую чиновники пытаются неумело оправдать тем, что ООО действуют по библейскому принципу: «главная сила дьявола уменье казаться не тем, что он есть» [29].

Фактически же это плата за липовый бренд и близость таких ООО к власти, а не за работу. В таком качестве вовлечение частного сектора в эффективное оказание услуг по обращению с TKO, разумеется, не может являться примером рациональной формы государственно-частного партнерства, а лишь демонстрирует фальсификацию активного выполнения «мусорной реформы». Например, тендер на вывоз мусора в Ярославской области (Родина лётчика-космонавта СССР, первой в мире женщины-космонавта, героя СССР, а ныне члена партии «Единая Россия», бессменного депутата государственной думы РФ В.В.Терешковой, 1937 г.р.) «выиграла» ООО «Хартия» (уставной капитал 10 тыс. руб. при стоимости одной мусороуборочной машины в среднем 6,5 млн. руб.) в которой 60\% акций принадлежат младшему сыну бывше- 
го генпрокурора РФ И.Ю. Чайке. Власти Ярославской области, обслуживая финансовые аппетиты именитого регоператора, который сам по себе лишь заурядный посредник между властью и привлекаемыми партнерами, заключили договор с этим ООО «Хартия» как единственным региональным оператором, выигравшим «конкурс» сроком на 9 лет, стоимость данного госконтракта составила 16 млрд. руб. Ранее, в 2015 году, ООО «Хартия» получила два аналогичных контракта сроком на 15 лет на вывоз мусора в Москве (Северо-Восточный и Восточный административные округа) на общую сумму в 42,6 млрд. руб. А в 2017 году заключила еще новые дополнительные госконтракты на 182 млн. руб. ООО «Хартия» также будет заниматься сбором и утилизацией мусора в границах Тулы, Щекинского и Киреевского районов Тульской области (долгосрочный контракт заключен на восемь лет). За посреднические услуги компания получит 10,3 млрд. руб. С 1 января 2019 года ООО «Хартия» доверили организацию сбора мусора в Ногинском кластере Московской области. Сумма контракта - 34,9 млрд. руб. [26].

Все это напоминает современный вариант бессмертной комедии Н.В. Гоголя «Ревизор», фразы из которой стали в русском языке крылатыми, как чайки, а имена героев нарицательными, когда мелкий чиновник самого низкого ранга из столичного Петербурга Иван Александрович Хлестаков (читай: Игорь Юрьевич Чайка из столичной Москвы) соглашается «взять деньги в долг» в виде «приношений от дворянства (читай: чиновников), суетливо бросающихся прикрывать свои грехи [21]. Так губернатор Ярославской области Д.Ю. Миронов (бывший начальник ГУЭБКиПК МВД РФ и впоследствии заместитель министра МВД РФ) единолично, игнорируя мнение жителей региона, дал разрешение принимать отходы из Москвы на местный полигон Скоково. На этом примере наглядно видно, что прием мусора из других регионов становится бизнесом для муниципальных властей. Деньги - главное, что мотивирует инициаторов этой затеи. Москва обещала перечислить в бюджет области 500 млн. руб. [45]. В общем, как писал в своем гениальном произведении «Горе от ума» другой классик русской литературы А.С. Грибоедов: «Дома новы, а предрассудки стары» [23].

В свою очередь не только у местных властей, но и у РЭО также имеются собственные интересы, права, нужды и потребности. Правительство постоянно испытывает на себе давление различных групп интересов в борьбе за финансирование «мусорной реформы». При этом несоблюдение принципа разделения властей, а также замещения правового законодательства политическим вносит в деятельность государства свои неподходящие коррективы. Здесь, по сути, имеет место совпадение или пересечение законодательной и исполнительной власти. В этом случае правительство, помимо распределения государственных ресурсов, занято еще определением их объема и порядка раздачи. На самом деле, как были подрядчики и субподрядчики, так они и остаются. Только теперь их нанимают, или берут в аренду (Мусоросжигательный завод МС3-4 передан ООО «Хартия» Москвой в аренду), не управляющие компании, а ООО - в качестве нового посредника, именуемые региональными операторами. То есть деньги шли в один карман, а пойдут в другой, как бы «государственный». При этом ситуация выглядит неустойчивой на фоне роста задолженности операторов-посредников перед компаниями, которые непосредственно фактически вывозят мусор,- расплатиться не удается по 3-6 месяцев. Когда операторы не смогут больше договариваться с вывозящими компаниями, которым задолжали, у муниципалитетов может не оказаться ни средств, ни техники, чтобы договориться самим [31]. Сейчас это превратилось в кабинетные игры на верху власти и дележку финансового пирога.

Национальный проект «Экология» оказался единственным, финансирование которого из федерального бюджета будет сокращено в следующие три года. В первую очередь правительство намерено сэкономить на реформе обращения с отходами, а именно на инвестициях, к сожалению, в строительство перерабатывающих мощностей. Финансирование будет уменьшено на $20 \%$ в 2020 г. и на $26 \%$ в 2021 г. до 10 млрд. и 12 млрд. руб. соответственно. В 2022 г. расходы понизятся незначительно - на 4\% до 17 млрд. руб. «Мусорная реформа» стала терять финансирование и из-за снижения поступлений в бюджет экологического сбора и ухода частных инвесторов. По данным Счетной палаты, прогноз поступлений сбора в 2017 году был уменьшен на 80,5\% - до 1,3 млрд. рублей [36]. А вследствие того, что коммунальные отходы являются депрессивной сферой на рынке концессий (от лат. concessio - «разрешение, уступка») вида договора о создании или реконструкции за счет средств инвестора (или - совместно с концедентом) объектов недвижимого имущества «мусорной реформы», инвесторы не чувствуют, что их вложения защищены из-за частых изменений правил. По данным Национальной ассоциации концессионеров и долгосрочных инвесторов в инфраструктуру (НАКДИ), в сфере коммунальных отходов все меньше число конкурсов на концессии, заключенных и реализованных соглашений. Если в 2017 году было заключено пять концессионных соглашений на 2,6 млрд. рублей, а в 2018 году - четыре на 8,2 млрд., то в 2019 году прошло три конкурса (НАКДИ отслеживает только средние и крупные проекты от 100 млн. до 1 млрд. и свыше 1 млрд. рублей). В бюджете на 2020 год на статью «Охрана окружающей среды» решено выделить 19,385 млрд. рублей, но при этом большая часть денег уйдет в автопром для выпуска авто, 
которые соответствуют стандартам Евро-4 и Евро-5. [36]. Все это подтачивает исполнение «мусорной реформы», поскольку практически не контролируется ее финансирование.

Следует отметить, что в ходе реализации федерального проекта «Комплексная система обращения с TKO» были допущены и другие более нежелательные ошибки и просчеты. Так, строительство новых полигонов было запланировано волевым порядком, кулуарно, без согласования с местными жителями. Это спровоцировало серьезные крупные столкновения между активистами и рабочими - строителями «мусорок». «Мусорные» протесты гораздо выше по своей интенсивности и накалу. Протестная активность идет не в каких-то суперогромных единомоментных масштабах, но она постоянная, размеры ее увеличиваются, число поводов растет. Например, осенью 2018 года власти Архангельской области насильственно, полностью проигнорировав протесты местных жителей, в угоду федеральных властей (губернатор Архангельской области М.А.Орлов) приняли решение о строительстве огромного мусорного экотехнопарка «Шиес», куда Минприродой РФ было намечено, несмотря на огромные транспортные расходы, свозить отходы из Москвы и Подмосковья. Но в результате мощного запроса в обществе на справедливость люди начали протестовать против жизни в помойке. Уже в 2019 году на фоне потери системы управления областью протест стал приобретать необратимый характер и грозил превратиться в условиях доведенного до нищеты населения, упадка экономики и высокого антирейтинга областной власти в беспощадный бунт типа народных восстаний Степана Разина и Емельяна Пугачева или Антоновского (тамбовского) и Кронштадтского мятежей. Поэтому в январе 2020 года Арбитражный суд Архангельской области был вынужден удовлетворить иск администрации Урдомского муниципального образования к ООО «Технопарк» о сносе капитальных построек, возведенных оператором строительства мусорного полигона на станции Шиес, где должны были приниматься отходы из Москвы. Однако у ООО «Технопарка» есть право обжаловать это решение в арбитражном апелляционном суде. «Помойщики» наверняка будут оспаривать данное постановление через опровержение проведенной экспертизы. Тем более что инициаторы идеи переброски мусора из Москвы планировали вложить в полигон 10,5 млрд. руб. и в области появится новый губернатор.

Исполнители в отчаянии пытаются привести в соответствие собственную деятельность по утилизации и переработке отходов с общественными интересами. В то же время у каждой ошибки есть конкретное имя, поскольку для реализации «мусорной реформы» ставят людей непрофессиональных, у которых нет понимания, какими будут долгосрочные последствия от нее. Нега- тивное влияние человеческого фактора из-за кризиса непрофессионализма заметно уже во многих сферах реформы, прежде всего в технологической. Если это будет продолжаться, то рано или поздно нас ждет бедствие, на фоне которого, возможно, померкнет и чернобыльская авария.

В стране, по данным Минприроды РФ, уже накоплено 40 млрд. тонн отходов, за год добавляется дополнительных 70 млн. тонн и каждый год - на 3\% больше, увеличивая площадь свалок на 500 тыс. га. ТКО выбрасываются в основном на несанкционированных площадях. В последние годы к биологическим и пищевым отходам в больших объемах добавились пластики, полимеры, электроприборы, содержащие токсические вещества. Перерабатывается же всего 5-7\%, остальное по-прежнему захоранивается [16]. По данным ТАСС, по объемам выбросов парниковых газов, в том числе из-за крайне запущенной проблемы ТБО, Россия сейчас занимает четвертое место в мире. Ежегодно от болезней, вызванных загрязненным воздухом, умирает 7 млн. человек во всем мире, а дышит чистым воздухом только один человек из 10. Это вызывает проблемы не только со здоровьем, но и с экономикой: снижается урожайность, производительность труда, растут расходы на здравоохранение. Загрязнение воздуха обошлось мировой экономике в 0,3\% ВВП в 2015 г., а расходы на социальную поддержку из-за него - еще в 6\% глобального ВВП [38]. 19 декабря 2019 г. в ходе большой пресс-конференции президент РФ Владимир Путин пообещал, что страна сократит вредные выбросы в атмосферу в том числе за счет увеличения углеродного сбора с промышленности минимум на 40 процентов [43]. В этой связи Российский союз промышленников и предпринимателей одновременно заявил, что повышение углеродного сбора с предприятий неизбежно приведет к дальнейшему росту тарифов ЖКХ для населения. В то же время в 2017 году выбросы углерода уже упали по сравнению с 1990 годом на 49\% по причине сворачивания промышленности, которое достигло в России катастрофических масштабов.

Подавляющее большинство, например, подмосковных полигонов создавалось в 70-80-х годах прошлого века. Тогда никаких особых технологий не применялось. В лучшем случае изучалась геология и выбирались участки с глинистыми почвами, чтобы хоть как-то попытаться уменьшить проникновение образующихся нечистот в землю и грунтовые воды. Ни одна подмосковная свалка не выстилалась, согласно нынешним современным требованиям, специальным многослойным материалом, который эти гниющие отходы мог бы удержать.

Параллельно из-за неудовлетворительных в инженерном плане сооружений «мусорок» систематически происходят выбросы вредных для здоровья отравляю- 
щих свалочных газов. В марте 2018 года жители Волоколамского района Московской области начали жаловаться на неприятный запах с местного мусорного полигона «Ядрово». Вскоре более 50 детей оказались в больницах с жалобами на плохое самочувствие. Это произошло из-за мощных выбросов в атмосферу токсичного газа со свалки. Но, несмотря на многочисленные справедливые митинги-протесты, на которых местные жители требовали полностью закрыть полигон, подмосковные власти стали лишь принимать мусор на другой новый участок той же свалки, мотивируя тем, что больше таких масштабов выбросов не допустят, поскольку действует новый экологический стандарт. На самом деле оказалось, что это очередная циничная дезинформация общественности. За красивым речевым оборотом - тысячи больных и преждевременно ушедших из жизни жителей Подмосковья - жертв политики экологического геноцида. Что такое новый экологический стандарт, Министерство экологии Московской области так конкретно и не объяснило.

В отсутствие инвестиционных мероприятий по строительству и модернизации полигонов существующие емкости для размещения TKO, оставшиеся в наследство от СССР, будут исчерпаны менее чем за три года. Ситуация грозит катастрофой в масштабах страны. Показательно, что в условиях дефицита оборудованных мест для сброса мусора даже одна из самых гигантских отравляющих жизнь миллионов жителей восточных районов столицы и Подмосковья региональных свалок - полигон «Кучино» в Балашихинском районе (Реутово, Никольское, Салтыковка) вблизи Москвы - была весьма неохотно закрыта из-за сопротивления местных властей только 23 июня 2019 г., несмотря даже на личное распоряжение Президента РФ.

Одним из направлений нацпроекта «Экология» является рекультивация (комплекс мер по экологическому и экономическому восстановлению земель и водных ресурсов, плодородие которых в результате человеческой деятельности существенно снизилось) полигонов и несанкционированных свалок. Характерно, что расходы на рекультивацию должны были закладываться в стоимость полигонов еще в процессе их проектирования. Однако это, как правило, игнорировалось. Кроме того, непрофессиональное проведение строительства полигонов ТБО и их последующей рекультивации может приводить к потере финансовых ресурсов и к локальной экологической катастрофе. По данным Минэкологии столичной области, общая площадь закрытых полигонов твердых бытовых отходов в Подмосковье превышает 40 га, а закрытых свалок составляет 274,6 га. Объем накопленных только на свалках отходов составляет 47,5 млрд. тонн. В 2019 году началась рекультивация пяти свалок в Подмосковье: «Кулаковский» (Чеховский округ),
«Аннино» (Рузский округ), «Долгопрудный» (одноименный муниципалитет), «Дубна Левобережная» (округ Дубна), «Царево» (Пушкинский округ). На эти пять проектов суммарно потребуется порядка 7,1 млрд. рублей.

В 2019-2021 годах планируется рекультивировать 15 из более чем 20 закрытых в Московской области мусорных полигонов. По данным властей, на эти цели потребуется порядка еще 20 млрд. рублей. На трех полигонах - «Каширский», «Быково», «Электросталь» работа уже завершена, а на четвертом, «Кучино», окончится в 2020 году. Всего с начала реформы отрасли обращения с отходами в Московской области на конец 2019 года количество закрытых мусорных полигонов составило 27 из 39. Оставшиеся 12 полигонов будут закрыты до 2030 года, два из которых в 2020 году будут модернизированы в современные комплексы по переработке отходов. Общая сумма на рекультивацию 24 закрытых объектов составляет около 25 млрд. рублей.

О том, что «мусорная реформа» давно назрела и необходима, никто сейчас и не спорит. Но практически полное отсутствие переработки вызывает рост импорта в Россию использованных бутылок и макулатуры из Белоруссии, Японии, Турции и других стран (!). За первые пять месяцев 2019 года он составил 9,6 тыс. тонн, что на 7\% превышает показатель аналогичного периода 2018 года [44]. Закупка иностранного мусора связана с тем, что запущенные в России предприятия по переработке отходов простаивают из-за отсутствия собственного сырья, поскольку в стране еще не введен раздельный сбор мусора. Повсеместные стихийные свалки, изжившие свои сроки и резервы, морально устаревшие полигоны ТKO, отравляющие людей и природу, игнорирование в течение долгого периода серьезных отечественных научных исследований в этой сфере, преждевременные смерти людей из-за ухудшающейся экологии - все это так. Поэтому закономерно, что значительная часть российского общества положительно восприняла вступление в силу Парижского соглашения (ПС) по климату в России в 2019 году [38]. Подавляющее большинство россиян солидарно с призывом экологической активистки - пятнадцатилетней шведской школьницы Греты Тунберг (страдает редким заболеванием - селективным мутизмом, или избирательной немотой, - постоянной неспособностью говорить в определенных условиях, например в обстановке социальной тревожности, несмотря на сохраненную способность нормально говорить в прочих ситуациях) - к незамедлительным действиям по борьбе с изменениями климата, в том числе и в соответствии с ПС. В целом принятие ПС для России - это только шаг, демонстрирующий всему миру, что мы понимаем экологические и климатические проблемы, но принципиально для страны ничего не меняющий. 
В этой связи настораживает весьма спорное и критикуемое авторитетными экспертами-экологами скороспелое решение властей о приравнивании мусоросжигания к переработке. Перспективы строительства сразу пяти (в Воскресенском, Наро-Фоминском, Ногинском и Солнечногорском районах Подмосковья и Татарстане) мусоросжигательных заводов (МС3) «по европейскому образцу», обсуждение будущих мусороплавильных производств в Сочи, Калининграде, Самаре, Якутии и т.д. вызывают обоснованную повышенную тревогу у жителей страны. Вопрос выброса диоксинов при мусоросжигании - самый острый и болезненный. Диоксин смертелен в концентрации 3,110-9 моль/кг, что в 150 тыс. раз сильнее аналогичной дозы цианида. Диоксины - это не одно вещество, а целая группа, и они чрезвычайно опасны для здоровья человека даже в самых ничтожных количествах. А поскольку слаженная система сортировки мусора в стране в целом реально отсутствует (она только на словах чиновников), с большой долей вероятности возникнут нештатные ситуации вплоть до залпового выброса. Кроме того, из всех производств по переработке и утилизации ТКО МСЗ самые дорогие - и в строительстве, и в эксплуатации. В связи с низким курсом рубля закупка импортного оборудования для этих предприятий значительно возрастет. Срок инвестиционной окупаемости проекта определен в 15 лет. Срок службы заводов довольно ограниченный: в России - 15-20 лет. К этому надо прибавить сложность и ненадежность газоулавливающих фильтров, необходимость в создании дорогостоящей инфраструктуры для хранения высокотоксичной золы и т.д.

Разумеется, ни о какой безопасности технологии и речи быть не может. Это экологическая бомба замедленного действия по сокращению продолжительности жизни людей. Например, Дания, которая занимает в Европе первое место по мусоросжиганию, лидирует и по количеству раковых заболеваний на душу населения. Федеральный закон от 27 декабря 2019 г. № 450-Ф3 [8], который приравнял «сожжение» мусора к его утилизации, тем самым позволил перенаправить деньги, выделяемые в рамках национальной программы «Экология», на строительство МСЗ. По высказываниям протестантов и их программным лозунгам становится ясно, что проблема «сжигания ТKО» волнует их не меньше, чем экологические угрозы, обусловленные складированием московского мусора в северных регионах. Сделанный упор на мусоросжигание вообще затормозит развитие в стране технологий раздельного сбора и последующей переработки отходов - самого перспективного пути, по которому сейчас идет весь развитый мир. Среди веских аргументов против мусоросжигания, выдвинутых экологическими организациями «РазДельный Сбор», «ЭКА» и Гринпис России,- мусо- росжигание наносит непоправимый ущерб здоровью населения и окружающей среде; мусоросжигание ведет к уничтожению ресурсов вместо их возврата в хозяйственный оборот и препятствует развитию отрасли вторичной переработки; электроэнергия от МС3 гораздо дороже существующих тарифов, ее нужно будет субсидировать из бюджета (а значит из налогов с населения) либо с помощью «зеленого тарифа» (а значит за счет повышения цен на товары народного потребления); признание энергии от сжигания отходов возобновляемой энергией незаконно и препятствует развитию реальной возобновляемой энергетики; приоритетная поддержка технологий мусоросжигания со стороны правительства противоречит законодательству РФ; лоббисты МСЗ ссылаются на опыт зарубежных стран, однако Еврокомиссия рекомендовала европейским странам отказываться от мусоросжигания и его госсподдержки в пользу раздельного сбора, переработки и сокращения образования отходов.

В итоге игнорирования доводов экологов вектор развития «мусорной реформы» по принципу «после нас хоть потоп» продолжает идти без должного научного обоснования в ужасной спешке и ложном направлении и приводит к многочисленным отрицательным результатам. В результате значительно выросли только цены за услугу по сбору, вывозу и утилизации мусора при реальном увеличении опасности для здоровья населения. Возникла ситуация, которая сейчас превратилась в проблему, фактически блокирующую первоначальные цели «мусорной реформы». Проще говоря, зловонный дым от свалки на полигонах исполнители реформы поменяли на еще более ядовитый смертельный дым от мусоросжигания, при этом «выпустив в трубу» миллиарды из бюджета (т.е. деньги населения).

Жители нашей страны хотят современного (с научной точки зрения) решения проблем с мусором. Нынешняя ситуация с TKO в России не устраивает в обществе самых разных людей. Недовольство существующим положением дел, когда из-за плохой экологии ни у кого нет спокойного завтрашнего дня, позитивного образа будущего экологии и люди живут в очень высоком состоянии стресса, не удовлетворяет всех. Население требует замены устаревших, часто носящих двусмысленный характер и противоречащих Конституции финансово-правовых норм на новые, позволяющие более эффективно применять методы правового регулирования, учитывать особенности финансового контроля при реальной, а не виртуальной утилизации мусора.

Bblводbl. В нынешнем виде «мусорная реформа» не может быть успешно осуществлена, поскольку она проводится непрофессионально, с большими финансовыми потерями и оторвана от реальной ситуации. Вме- 
сто того чтобы увеличивать государственные доходы путем создания мусороперерабатывающих заводов, реформаторы просто приписали каждому гражданину нашей страны еще один обязательный платеж. Количество имеющихся и вновь созданных организаторами реформы сложных проблем превышает возможности страны со стагнирующей экономикой, ослабленной эпидемией коронавируса и разоренным значительным числом населения. «Мусорная реформа» в нынешнем виде должна быть существенно переработана на основе научных исследований, исходя из реальных возможностей государства и выявленных недостатков.

\section{ЛИТЕРАТУРА}

1. Конституция (Основной Закон) Российской Федерации [принята всенародным голосованием 12.12.1993]: (с учетом поправок, внесенных Законами РФ о поправках к Конституции РФ от 30.12.2008 № 6-ФК3, от 30.12.2008 № 7-ФК3, от 05.02.2014 № 2-ФК3, от 21.07.2014 № 11-ФК3) // С3 РФ.— 2014.— № 31.- - С. 4398

2. Гражданский кодекс РФ: Часть первая — четвертая: [принят Государственной Думой 21 октября 1994 г.] // Актуальная редакция ГК РФ от 16.12 .2019 г. (с изменениями, вступившими в силу с 01.01.2020 г.)

3. О защите прав потребителей: Федеральный закон от 09.01.1996 № 2300-01-Ф3: (с изменениями: от 17.12.1999 № 212-Ф3, от 30.12.2001 № 196-Ф3, от 22.08.2004 № 122-Ф3, от 02.11.2004 № 127-Ф3, от 21.12.2004 № 171-Ф3, от 27.07.2006 № 140-Ф3, от 16.10.2006 № 160-Ф3, 0т 25.11.2006 № 193-Ф3, от 25.10.2007 № 234-Ф3, от 23.07.2008 № 160-Ф3, от 03.06.2009 № 121-Ф3, от 23.11.2009 № 261-Ф3, от 27.06.2011 № 162-Ф3, т 18.07.2011 № 242-Ф3, от 25.06.2012 № 93-Ф3, от 28.07.2012 № 133-Ф3, от 02.07.2013 № 185-Ф3, от 21.12.2013 № 363-Ф3, от 05.05.2014 № 112-Ф3, от 13.07.2015 № 233-Ф3, от 03.07.2016 № 265-Ф3, от 01.05.2017 № 88-Ф3, от 18.04.2018 № 81-Ф3, от 04.06.2018 № 133-Ф3, от 29.07.2018 № 250-Ф3, от 18.03.2019 № 38-Ф3, от 18.07.2019 № 191-Ф3) // publication.pravo.gov.ru Официальный интернет-портал правовой информации. Государственная система правовой информации.

4. 0 противодействии легализации (отмыванию) доходов, полученных преступным путем, и финансированию терроризма: Федеральный закон от 07.08.2001 г. № 115-Ф3: [принят Государственной Думой 13 июля 2001 г.: одобрен Советом Федерации 20 июля 2001 г.]: (с изм. и доп., вступ. В силу c 01.01.2020 г.) //publication.pravo.gov.ru 0фициальный интернет-портал правовой информации. Государственная система правовой информации.

5. Жилищный кодекс Российской Федерации: Федеральный закон № 188-Ф3: [принят Государственной Думой 22 декабря 2004 г.: одобрен Советом Федерации 24 декабря 2004 г.]: (ред. от 6 февраля 2020 г.) // publication.pravo.gov.ru Официальный интернет-портал правовой информации. Государственная система правовой информации.

6. 0 внесении изменений в Федеральный закон «06 отходах производства и потребления»: Федеральный закон от 29.12.2014 г. № $458-$ Ф3 [принят Государственной Думой 23 декабря 2014 г.: одобрен Советом Федерации 25 декабря 2014 г.] // publication.pravo.gov.ru 0фициальный интернет-портал правовой информации. Государственная система правовой информации.

7. 0 внесении изменений в Федеральный закон «06 отходах производства и потребления»: Федеральный закон от 31.12 .2017 г. № $503-$ Ф3 [принят Государственной Думой 22 декабря 2017 г.: одобрен Советом Федерации 26 декабря 2017 г.]: (последняя редакция) // publication.pravo.gov.ru 0фициальный интернет-портал правовой информации. Государственная система правовой информации.

8. 0 внесении изменений в отдельные законодательные акты Российской Федерации: Федеральный закон от 27.12.2019 г. № 450-Ф3 [принят Государственной Думой 18 декабря 2019 г.: одобрен Советом Федерации 23 декабря 2019 г.] // publication.pravo.gov.ru 0фициальный интернет-портал правовой информации. Государственная система правовой информации.

9. 0 национальных целях и стратегических задачах развития Российской Федерации на период до 2024 года: указ Президента РФ от 07.05 .2018 г. № 204 // Российская газета — Федеральный выпуск № 75601 (97).— 9 мая 2018 г.

10. 06 упорядочении деятельности совещательных и консультативных органов при Президенте Российской Федерации: указ Президента РФ от 19.07 .2018 г. № 444 // www.kremlin.ru

11. 0 создании публично-правовой компании по формированию комплексной системы обращения с твёрдыми коммунальными отходами «Российский экологический оператор»: указ Президента РФ от 14 января 2020 г. № 8 // publication.pravo.gov.ru Официальный интернет-портал правовой информации. Государственная система правовой информации.

12. О Правительстве Российской Федерации: указ Президента РФ от 15 января 2020 г. № 14// publication.pravo.gov.ru 0фициальный интернет-портал правовой информации. Государственная система правовой информации.

13. 0 предоставлении коммунальных услуг собственникам и пользователям помещений в многоквартирных домах и жилых домов: постановление Правительства РФ от 6 мая 2011 г. № 354 (с изменениями и дополнениями на 20.12.2018г.) // publication.pravo.gov.ru 0фициальный интернет-портал правовой информации. Государственная система правовой информации.

14. Правила осуществления деятельности по управлению многоквартирными домами: постановление Правительства РФ от 15 мая 2013 г. № 416 (ред. 13.09.2018 г.) // publication.pravo.gov.ru 0фициальный интернет-портал правовой информации. Государственная система правовой информации.

15. 06 утверждении положения о постановке на учет в федеральной службе по финансовому мониторингу организаций, осуществляющих операции с денежными средствами или иным имуществом, и индивидуальных предпринимателей, в сфере деятельности которых отсутствуют надзорные органы: постановление Правительства РФ от 27 января 2014 г. № 58 (ред. от 28.11.2017 г.) // publication.pravo.gov.ru 0фициальный интернет-портал правовой информации. Государственная система правовой информации. 
16. 06 обращении с твердыми коммунальными отходами и внесении изменения в постановление Правительства Российской Федерации от 25 августа 2008 г. № 641: постановление Правительства РФ от 12.11.2016 № 1156 (ред. от 15.12.2018 г.) // publication.pravo.gov.ru. Официальный интернет-портал правовой информации. Государственная система правовой информации.

17. Паспорт национального проекта «Экология»: [утвержден президиумом Совета при Президенте Российской Федерации по стратегическому развитию и национальным проектам (протокол от 24 декабря 2018 года № 16)].

18. 06 утверждении нормативов накопления твердых коммунальных отходов на территории Московской области: распоряжение Министерства экологии и природопользования Московской области от 01.08.2018 г. № 424-PM //mep.mosreg.ru

19. 0 внесении изменений в распоряжение Министерства экологии и природопользования Московской области от 01.08.2018 г. № $424-$ РМ «06 утверждении нормативов накопления твердых коммунальных отходов на территории Московской области»: распоряжение Министерства экологии и природопользования Московской области от 09.10.2018 г. № 607-PM // mep.mosreg.ru

20. Российский статистический ежегодник. 2019.- М., 2019.

21. Гоголь, Н. В. Ревизор / Н. В. Гоголь.- М.: Эксмо, 2017. - 672 с.

22. Голиченков, А. К. Экологическое право России: словарь юридических терминов / А. К. Голиченков. — М.: Городец, 2012. — 512 с.

23. Грибоедов, А. С. Горе от ума / А. С. Грибоедов. - М.: Эксмо, 2020.- 160 с.

24. Финансовое право: учебник / А. Ю. Ильин, В. А. Яговкина, М. Н. Кобзарь-Фролова [и др.]; под общей редакцией И. И. Кучерова.— М.: Эксмо, 2011.—590 c.

25. Кобылкин, Д.Н. «В уходе заведомо слабых игроков с рынка я никакой трагедии не вижу»: интервью министра природных ресурсов и экологии РФ Российской газете. // Российская газета.— 9 декабря 2019 года.

26. Ляув, Бэла. Игорь Чайка становится крупнейшим оператором по мусору. // Ежедневная деловая газета Ведомости\&. - 26 aпреля 2018 vedomosti.ru

27. Лобко, А. А. Некоторые проблемы реализации конституционного права граждан на социальное обеспечение // Современная наука. Актуальные проблемы теории и практики. Серия «Экономика и право».— 2019.— № 6. - С. 131-137.

28. Питер, Лоуренс Джонстон. Принцип Питера, или почему дела идут вкривь и вкось / Лоуренс Джонстон Питер. — М.: Издательство АСТ, 2002.

29. Мережковский, Д. С. Гоголь и черт / Д. С. Мережковский. - М.: Книговек, 2010. - 384 с.

30. Мереминская, Е. Правительство просит регионы ввести раздельный сбор отходов. И пересмотреть территориальные схемы обращения с мусором // Ежедневная деловая газета Ведомости\&.— 06 мая 2019 г. vedomosti.ru

31. Мереминская, Е. Мусорная реформа под угрозой: Многие операторы оказались на грани банкротства. / Е. Мереминская, А. Червонная // Ежедневная деловая газета Ведомости\&.— 08 августа 2019 г. vedomosti.ru

32. Поветкина, Н. А. Правовые средства обеспечения финансовой безопасности / Н. А. Поветкина, И. И. Кучеров, 0. А. Акопян. 一 М.: Норма, 2019. 一 240 с.

33. Райзберг, Б.А., Лобко А. Г. Программно-целевое планирование и управление»: учебник / Б. А. Райзберг, А. Г. Лобко. - М.: ИНФРА-М, 2002.

34. Труссон, Реймон. Жан-Жак Руссо / Реймон Труссон. - М.: Молодая гвардия, 2015. - 322 с.

35. Хайек, Ф. Конституция свободы / Ф. Хайек; пер. Б. Пинскер. - М.: Новое издательство, 2018. - 528 с.

36. Финансирование мусорной реформы из бюджета сократится // Ежедневная деловая газета Ведомости\&. - 17 октября 2019 года. vedomosti.ru

37. «Вы поймите, мусорный вопрос — чисто политический». Почему «мусорная реформа» пошла не туда и вызывает недовольство граждан. Интервью В. Кузнецова // Интернет-газета ZNAK. - 1 февраля 2019 года.

38. Грязный воздух уменьшает ВВП. РФ возглавила рейтинг стран, теряющих от загрязнения атмосферы // Коммерсантъ.— № 132 (6126).— 24 июля 2017 года.

39. Парижское соглашение впишется в закон. Россия ратифицирует его до конца сентября // Коммерсантъ. — № 118 (6598). — 9 июля 2019 года.

40. Глава СПЧ ... оказался сотрудником администрации Президента // Коммерсантъ.— № 24 (6745). — 11 февраля 2020 года.

41. В ЖКХ заманивают инвесторов. Минэкономики предлагает скорректировать процедуру заключения концессионных соглашений // Коммерсантъ.№ 43 (6764) - 11 марта 2020 года.

42. Россиян предупредили о резком росте цен на бытовую технику // Газета. Ru. - 25 февраля 2020 года.

43. Путин пообещал сократить вредные выбросы в атмосферу // Lenta.ru - 19 декабря 2019 года.

44. Эксперты отмечают рост импорта в Россию вторичного пластика и макулатуры // news.solidwaste.ru — актуальная и своевременная информация отрасли коммунальных и промышленных отходов. 29 августа 2019 года.

45. Москва заплатила 500 миллионов за свой мусор: как их потратили в Ярославской области. Новости Ярославля и Ярославской области. //https: yaroslavl. bezformata.com. 13 ноября 2019 года.

(с) Лобко Анастасия Александровна ( naty.rubik@mail.ru ).

Журнал «Современная наука: актуальные проблемы теории и практики» 